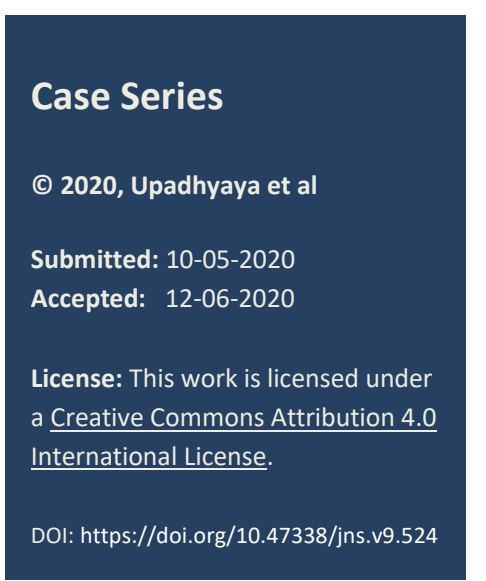

\title{
Colonic stenosis in neonates is not always congenital or complication of necrotizing enterocolitis
}

\author{
Vijai Datta Upadhyaya, * Ashwani Mishra, Yusuf Md, Basant Kumar
}

Department of Pediatric Surgery, SGPGIMS, Lucknow

Correspondence*: Vijai Datta Upadhyaya, Department of Pediatric Surgery, SGPGIMS, Lucknow.

E-mail: upadhyayavj@rediffmail.com

\section{KEYWORDS \\ Stenosis \\ Colon \\ Atresia \\ Hirschsprung disease}

\section{ABSTRACT}

Background: Bowel obstruction in early infancy may results from variety of congenital anomalies involving small and large bowel. Colonic stenosis (CS) congenital or acquired is among the rare causes of chronic bowel obstructions in early infancy.

Methods: Medical record of 4 patients with colonic stenosis secondary to Hirschsprung's disease was reviewed.

Results: A total of 4 cases were included in the study. Age of presentation ranged from 25 days to 96 days. Most common presentation was gross abdominal distension with visible bowel loop, vomiting, difficulty in passing stool followed by history of passing recurrent loose stools and failure to thrive. In one case there was suspicion of bowel perforation and was operated in emergency. Initial operative findings and histopathology was not suggestive of Hirschsprung's Disease, but a full thickness rectal biopsy confirmed HD in all 4 cases.

Conclusion: Hirschsprung should be considered as underlying pathology in cases of colonic stricture/stenosis in children.

\section{INTRODUCTION}

Bowel obstruction in early infancy may result from a variety of congenital anomalies involving the small and large bowel. Colonic stenosis (CS), which can be either congenital or acquired, is among the rare causes of chronic bowel obstruction in early infancy.[1] Congenital intestinal stenosis is a malformation of the wall of the intestine in which the dilated proximal segment is in continuity with the distal segment by a short, narrow, and rigid segment with minimal lumen and intact intestinal mesentery.[2]

Acquired CS may result from insults on the bowel wall following necrotizing enter colitis (NEC), TORCH, and bacterial infection.[3] CS is exceedingly unusual and only 16 cases have been reported in the literature between 1968 and 2016, the lesions of which are approximately equally divided between being proximal and distal to the splenic flexure of the colon.[3-8]. This case series describes 4 cases of acquired CS secondary to Hirschsprung's disease (HD).

\section{MATERIALS AND METHODS}

Medical record of 4 cases of acquired CS secondary to HD, presented between July 2013 to July 2019 to Department of Pediatric Surgery, SGPGIMS Lucknow, was reviewed for the demography, clinical presentation, management done, and the outcome.

\section{RESULTS}

All cases were full term and age of presentation ranged from 25 days to 96 days. The male-to-female ratio was $3: 1$, median weight was $2.5 \mathrm{~kg}$, and median age was 36days. Most common presentation was gross abdominal distension with visible bowel loop followed by failure to thrive. History of enterocolitis was present in $3(75 \%)$ cases and vomiting in $2(50 \%)$ cases. One case presented with suspicion of bowel perforation on X-ray abdomen and clinical findings, thus operated on emergent basis. Rest of the cases were operated electively after investigation of the cause. Barium enema was done in other 2 cases to locate the site of obstruction (Fig. 1). 
Endoscopy was done in 1 case preoperatively where we were unable to negotiate beyond splenic flexure. After preliminary resuscitation and investigations, exploratory laparotomy was done in all cases. CS (Fig. 2) was in left colon in all cases. All cases were managed by resection of the involved bowel, biopsy from distal part of the colon and stoma formation. The biopsies from distal colon were positive for ganglion cells. Full thickness rectal biopsy was done to rule out Hirschsprung Disease before closure of the stoma that revealed absence of ganglion cells. Therefore, Duhamel Pull through was done in these patients as a definitive procedure. In all underlying pathology for CS was HD. Patients have been on followed up for 2 years after definitive surgery, and all are doing well. Table 1 describes summary of the study cases.

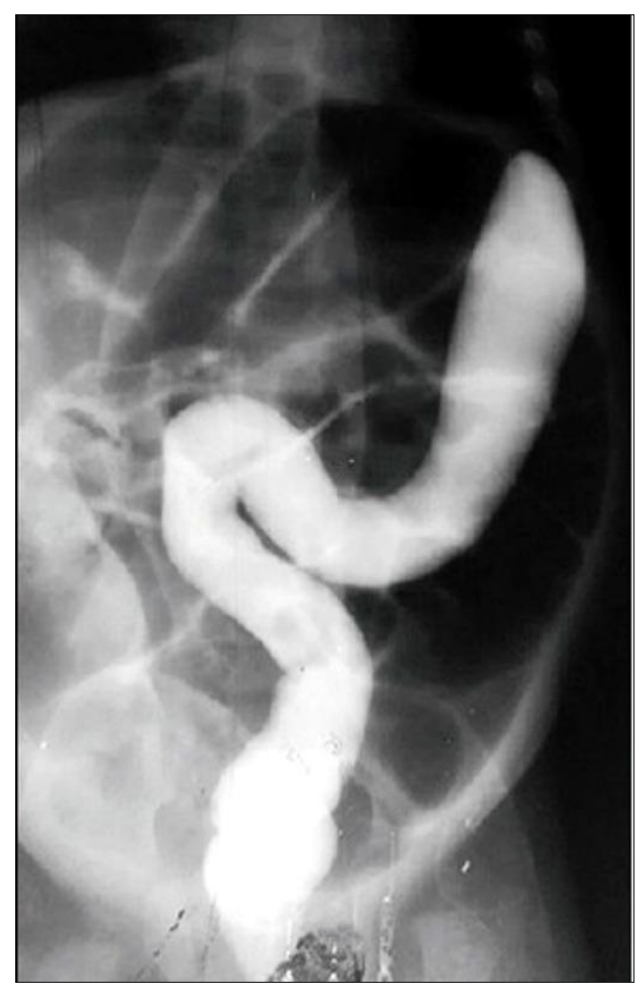

Figure 1: Barium enema showing contrast not traversing beyond the splenic flexure.

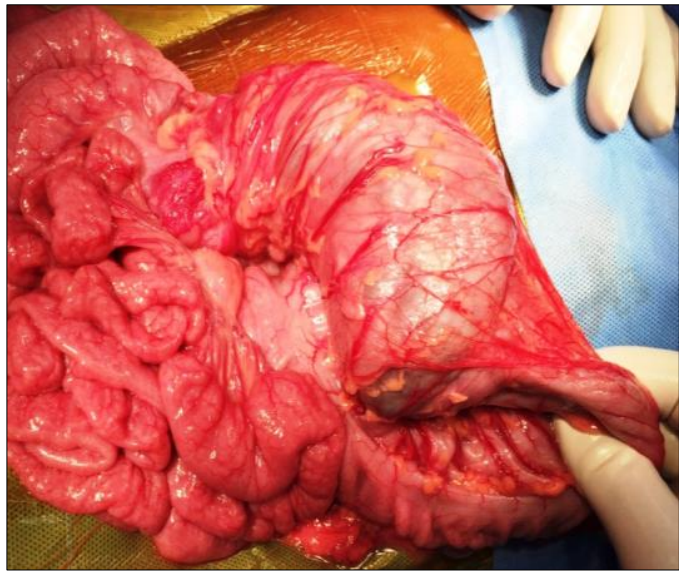

Figure 2: Showing stenosis at descending colon.

\section{DISCUSSION}

CA is a congenital deformity, whereas CS may be congenital or acquired from (secondary to) other diseases.[6-11] CS is a rare but known cause of pediatric intestinal obstruction which may present during neonatal age, early infancy, or rarely after infancy.[4,12] The presentations of CA and CS are similar; the only difference between them is the age of presentation. CA presents within a few days of life, requiring urgent surgery because of closed-loop obstruction, which may lead to bowel necrosis and perforation. In cases of CS, patients may remain asymptomatic for varying periods of time, making diagnosis difficult.[12] Factors that determine the time of presentation are related to the transition to solid foods, length of the involved bowel, and severity of the stenosis.[12] of the involved bowel. In our view, one of the major reasons for the delayed presentation of acquired CS is that every lesion takes time to develop after an insult, which may be infective or vascular.[4] In most of published series, age of presentation was first few days of life [13], probably because the cases included were mainly congenital. In present series, median age presentation was 36 days probably because we included cases of acquired and is similar to the reported series of acquired CS in children. $[4,8,12,14]$

In none of present cases, operative finding or HPE of the excised bowel suspected HD. Histopathological examinations (HPE) findings were non-specific and mostly showed denudation of lining epithelium and deposition of granulation tissue, capillaries and mixed inflammatory cells comprising of neutrophils, lymphocytes and histiocytes at site of stenosis. We hypothesize that recurrent enterocolitis induced inflammatory response in bowel wall, which in turn led to the eventual development of stenosis of the involved region.

The most common cause of secondary CS is insult on the bowel in NEC followed by CMV (TORCH) infection. Review of English literature revealed that the association of HD is well known with colonic atresia, but its association with acquired CS is not well reported.[1520] We presented here 4 cases of acquired CS secondary to HD.

Contrast enema in typical cases of CS, delineates a small caliber distal colon and distended proximal colon. It can also differentiate CS from CA as in latter the findings are a cut-off point between the distal colon filled with contrast and dilated proximal bowel filled with luminal air. Sometimes, a barium enema study is not possible either due to limited availability during the emergency period or due to a poor general condition of the patient wherein it is not advisable. In our opinion, colonoscopy is one of the diagnostic tools for this condition, but sometimes, stenosis is severe such that negotiation of the scope is not possible [19], as encountered in one of our cases. However, endoscopy 
requires expertise and it is sometimes not possible due to the risk of complications considering the poor general condition of the patient.

In the present series, endoscopy was done in 1 case and a barium study was performed in two cases, whereas in one case operation was done on X-ray finding and clinical evaluation. In the present series, the affected part of the bowel was excised in all cases, and proximal-end stoma and distal mucus fistula were formed as stage -1 . Rectal biopsy was done to rule out HD in second stage followed by definitive surgery (Duhamel's Pull-through) in third stage. Staged surgery has also been advised by various authors [12,18] but none of them emphasized ruling out HD in cases of CS. Most reported series do not favor or recommend rectal biopsy before definitive surgery for CS either primary or staged [15-20]. We strongly emphasize the role of rectal biopsy in ruling out HD in cases of acquired CS before definitive surgery.

\section{CONCLUSION}

Colonic stenosis is relatively a rare disease and should be suspected in the large bowel obstruction in newborn and children in first two years of life. It is advisable to rule out Hirschsprung Disease by rectal biopsy before definitive procedure.

Acknowledgements: We acknowledge the pathologist for prompt re-
porting of the specimen to rule out HD; and Editage Author Services to edit the manuscript.

\section{Conflict of Interest: None declared}

Source of Support: $\mathrm{Ni}$

Consent to Publication: Author(s) declared taking informed written consent for the publication of clinical photographs/material (if any used), from the legal guardian of the patient with an understanding that every effort will be made to conceal the identity of the patient, however it cannot be guaranteed.

Author Contributions: Author(s) declared to fulfil authorship criteria as devised by ICMJE and approved the final version.

Table 1: Showing the summary of the cases

\begin{tabular}{|c|c|c|c|c|c|}
\hline $\begin{array}{l}\text { Case } \\
\#\end{array}$ & $\begin{array}{l}\text { Age / } \\
\text { Sex / } \\
\text { Weight }\end{array}$ & $\begin{array}{l}\text { Clinical } \\
\text { presentation }\end{array}$ & $\begin{array}{l}\text { Radiological } \\
\text { Investigation }\end{array}$ & $\begin{array}{l}\text { Operative Finding and } \\
\text { Histopathology }\end{array}$ & Operative Procedure \\
\hline 1 & $\begin{array}{l}25 \text { days } \\
\text { Male } \\
2.1 \mathrm{~kg}\end{array}$ & $\begin{array}{l}\text { Abdominal } \\
\text { distension, } \\
\text { vomiting, failure } \\
\text { to thrive, } \\
\text { difficulty in } \\
\text { passing stool }\end{array}$ & $\begin{array}{l}\text { X-ray Showed } \\
\text { Multiple air } \\
\text { fluid level, } \\
\text { barium enema } \\
\text { showed blind } \\
\text { ending colon }\end{array}$ & $\begin{array}{l}\text { Stenosis of descending colon } \\
\text { HPE: Granulation tissue, } \\
\text { capillaries and mixed } \\
\text { inflammatory cells comprising } \\
\text { of neutrophils, lymphocytes } \\
\text { and histiocytes at site of } \\
\text { stenosis }\end{array}$ & $\begin{array}{l}\text { (1) Exploratory laparotomy, } \\
\text { double barrel stoma, biopsy } \\
\text { from colon distal to the } \\
\text { stenosed bowel } \\
\text { (2) Full thickness rectal } \\
\text { biopsy- feature of HD (3) } \\
\text { Duhamel pull through }\end{array}$ \\
\hline 2 & $\begin{array}{l}32 \text { days } \\
\text { Male } \\
2.7 \mathrm{~kg}\end{array}$ & $\begin{array}{l}\text { Recurrent } \\
\text { enterocolitis, mild } \\
\text { abdominal } \\
\text { distension, } \\
\text { failure to thrive, } \\
\text { sepsis, } \\
\text { constipation }\end{array}$ & $\begin{array}{l}\text { X-ray showed } \\
\text { multiple air } \\
\text { fluid levels. } \\
\text { Suspicion of } \\
\text { pneumoperitone } \\
\text { um }\end{array}$ & $\begin{array}{l}\text { Stenosis at the distal } \\
\text { descending colon/Proximal } \\
\text { sigmoid colon. No feature of } \\
\text { bowel perforation } \\
\text { HPE: denudation of lining } \\
\text { epithelium with thinned out } \\
\text { mucosa. The lining epithelium } \\
\text { show mild reactive atypia in } \\
\text { places and inflammatory cells } \\
\text { like histiocytes }\end{array}$ & $\begin{array}{l}\text { (1)Exploratory laparotomy, } \\
\text { double barrel stoma, biopsy } \\
\text { from stricture site } \\
\text { (2) Full thickness rectal } \\
\text { biopsy - Feature of HD) (3) } \\
\text { Duhamel Pull through }\end{array}$ \\
\hline 3 & $\begin{array}{l}\text { 40days } \\
\text { Female } \\
2.3 \mathrm{~kg}\end{array}$ & $\begin{array}{l}\text { Abdominal } \\
\text { distension, } \\
\text { vomiting usually } \\
\text { non bilious, } \\
\text { passing liquid } \\
\text { stool with } \\
\text { staining }\end{array}$ & $\begin{array}{l}\text { X-ray: Dilated } \\
\text { bowel loop } \\
\text { Barium Study: } \\
\text { barium not } \\
\text { passing beyond } \\
\text { splenic flexure } \\
\text { Endoscopy not } \\
\text { negotiable }\end{array}$ & $\begin{array}{l}\text { Stenosis at splenic flexure, No } \\
\text { feature of malrotation, no } \\
\text { feature of HD } \\
\text { HPE: marked increase in } \\
\text { lymphomononuclear } \\
\text { inflammatory cell infiltrate. The } \\
\text { submucosa shows congested } \\
\text { vascular channels }\end{array}$ & $\begin{array}{l}\text { (1)Exploratory laparotomy, } \\
\text { end stoma after excision of } \\
\text { stenosed area and distal } \\
\text { mucous fistula } \\
\text { (2) full thickness rectal } \\
\text { biopsy - Feature of HD (3) } \\
\text { Duhamel pull through }\end{array}$ \\
\hline 4 & $\begin{array}{l}96 \text { days } \\
\text { Male } \\
3.5 \mathrm{~kg}\end{array}$ & $\begin{array}{l}\text { Abdominal } \\
\text { distension, } \\
\text { recurrent } \\
\text { enterocolitis, } \\
\text { occasional bilious } \\
\text { emesis, pass } \\
\text { small liquid stool, } \\
\text { delayed passage } \\
\text { of meconium }\end{array}$ & $\begin{array}{l}\text { X-ray: dilated } \\
\text { bowel loops }\end{array}$ & $\begin{array}{l}\text { Small bowel moderately } \\
\text { dilated, colon mildly dilated, } \\
\text { stricture at descending colon. } \\
\text { HPE: Granulation tissue, } \\
\text { capillaries and mixed } \\
\text { inflammatory cells comprising } \\
\text { of neutrophils, lymphocytes } \\
\text { and histiocytes at site of } \\
\text { stenosis }\end{array}$ & $\begin{array}{l}\text { (1)Exploratory laparotomy, } \\
\text { end stoma after excision of } \\
\text { stenosed area and distal } \\
\text { mucous fistula } \\
\text { (2) full thickness rectal } \\
\text { biopsy - Feature of HD (3) } \\
\text { Duhamel pull through }\end{array}$ \\
\hline
\end{tabular}




\section{REFERENCES}

1. Etensel B, Temir G, Karkiner A, Melek M, Edirne Y, Karaca I, et al. Atresia of the colon. J Pediatr Surg. 2005; 40:1258-68

2. Keith TO, Arca MJ. Atresia, stenosis, and other obstruction of the colon. In: Grosfeld JL, O'Neill JA Jr, Coran AG, Fonkalsrud EW, eds. Pediatric Surgery. 6th ed. Philadelphia: Mosby; 2006; 1493-1500.

3. Elisa Z, Cinzia C, Sergio S, Giuseppe LV, Fortunato S. Multiple congenital colonic stenosis: A rare gastrointestinal malformation. Case Rep Pediatr. 2016: https://doi.org/10.1155/2016/6329793.

4. Galván-Montaño A, Suárez-RoaMde L, CarmonaMoreno E. Congenital stenosis of the colon with foreign bodies. Case report. Cir. 2010; 78:259-61.

5. Powell RW, Raffensperger JG. Congenital colonic atresia. J Pediatr Surg. 1982; 17:166-70.

6. Abu-Judeh HH, Methratta S, Ybasco A, Garrow E, Ali S. Congenital colonic stenosis South Med J. 2001; 94:3446.

7. Lim IIP, Durbin J, Tomita S. Colonic stenosis in infant with connective tissue disorder. J Ped Surg Case Rep. 2013: $1: 340-2$

8. Ruggeri G, Libri M, Gargano T, Pavia S, Pasini L, Tani $\mathrm{G}$, et al. Congenital colonic stenosis: a case of lateonset. Pediatr Med Chir. 2009; 31:130e3

9. Erskine JM. Colonic stenosis in the newborn: The possible thromboembolic etiology of intestinal stenosis and atresia. J Pediatr Surg. 1970; 5:321-33.

10. Mirza B, Iqbal S, Ijaz L. Colonic atresia and stenosis: Our experience. J Neonatal Surg. 2012; 1:4.

11. Marseglia L, Manti S, D’Angelo G, Lima M, Impellizzeri $\mathrm{P}$, Romeo $\mathrm{C}$, et al. Colonic stenosis post-necrotizing enterocolitis in term new-born with acquired cytomegalovirus infection. Chirurgia (Bucur). 2015; 110:175-8.

12. Pelizzo G, Nakib G, Goruppi I, Fusillo M, Scorletti F, Mencherini S, et al. Isolated colon ischemia with norovirus infection in preterm babies: a case series. J Med Case Rep. 2013; 7:108.

13. Hamid R, Ali I, Bhat N, Baba AA, Mufti G, et al. Management od congenital colonic stenosis. J Neonatal Biol. 2015; 4:166.

14. Mizuno M, Kato T, Hebiguchi T, Yoshino H. Congenital membranous colonic stenosis-case report of an extremely rare anomaly. J Pediatr Surg. 2003; 38:13-5.

15. Kim CW, Superina RA, Ein S. Colonic atresia combined with Hirschsprung's disease: a diagnostic and therapeutic challenge. J Pediatr Surg. 1995; 30:12167.

16. Williams MD, Burrington JD. Hirschsprung's disease complicating colonic atresia. J Pediatr Surg. 1993; 28:637-9.

17. Sharma SB, Gupta V, Sharma V. Hirschsprung's disease complicating colonic atresia. Indian J Pediatr. 2004; 71:445-6.

18. Hamid R, Shera AH, Bhat NA, Baba A, Rashid A Congenital descending colonic stenosis with perforation of transverse colon in a neonate: A case report. J Nepal Paediatr Soc. 2012; 32:73-5.

19. Ekenze SO, Ezomike UO, Nwachukwu IE. Chronic bowel obstruction from colonic stenosis in early infancy-A report of two cases. Malawi Med J. 2019; 31:82-5

20. Bharti LK, Kumar B, Upadhyaya VD, Rao RN, Kumar S. Unusual presentation of congenital stenosis of sigmoid colon: Case report. J Surg Tech Proced. 2017; 1:1002. 